\title{
FACTORS AFFECTING JOB SATISFACTION AMONG UNIVERSITY FACULTY
}

\author{
Asma Zia \\ Lecturer, \\ Institute of Education, University of Azad Jammu and Kashmir, \\ AJK, Pakistan \\ Email: asmazia04@gmail.com

\section{Manzoor Hussain Shah} \\ Professor, \\ Department of Education, Hazara University Mansehra, \\ KPK, Pakistan \\ Email: drmhshaah@gmail.com \\ Bibi Asia Naz \\ Assistant Professor, \\ Department of Education, Hazara University Mansehra, \\ KPK, Pakistan \\ Email: asianaz@awkum.edu.pk
}

\begin{abstract}
Job satisfaction is a growing topic in the field of educational settings. Universities are the backbone of any country in which the teachers are producing the leaders, engineers, doctors, politicians etc. for their careers and practical life. Satisfied teachers produce the adults in a positive way and dissatisfied teachers have negative effects on the adults. The current study is about the job satisfaction of university faculty in Azad Jammu \& Kashmir. The objective of the study was to explore the job satisfaction of the university faculty. 541 university faculty members were selected from the five public sector universities of Azad Jammu \& Kashmir through stratified sampling technique. The study was quantitative in nature, survey method was used and a self-structured questionnaire on five point likert type scale was used to collect the relevant data. Analysis of data done through frequency, percentage and mean score. Results of the study showed that faculty members are satisfied with their job as it is permanent, satisfied with the study leave policy of the faculty, enjoying good relationship with colleague, satisfied with university act and statutes, getting a handsome salary and MPhil \& PhD allowance. However, they are dissatisfied with the physical environment of the university does not positively contribute towards their health and physical facilities provided in the university are not enough for their teaching leaning process.
\end{abstract}




\section{KEYWORDS}

Faculty, job satisfaction, Job Security, Pay, motivation, Relationship with Colleagues, Working Environmental Conditions

\section{INTRODUCTION}

Job satisfaction in a work place is a feeling of contentment that an employee derive from his/her Role and responsibilities in the workplace. Job satisfaction could be defined in a sense as the level to which an individual is satisfied with the rewards he/she gets out of his or her job, mostly in terms of intrinsic motivation (Statt, 2004). Armstrong (2006) was in the view that job satisfactions refers to the feelings and attitudes of people about their work. People with positive and favourable attitudes towards their job indicate job satisfaction. People having negative and harsh attitudes towards their job show job dissatisfaction among them.

Nobody can deny the importance of job satisfaction especially in the educational institutions. Educational institutes and specifically universities play important role in the building the characters of the students who live in the society. Satisfied faculty build up the characters of the students in a positive way and dissatisfied faculty perform badly. Job dissatisfaction leads many negative consequences such a lack of loyalty towards universities, absenteeism, increase number of accidents etc. Spector (1997) lists three important characteristics of job satisfaction. Firstly the organizations should always be guided by human values. Secondly, attitude of workers reliant on their level of job satisfaction would influence the activities and functioning of the organization's business. Last, job satisfaction may be serving as determinants of organization's activities. It can be said that satisfied university faculty perform better in the universities and increase the productivity and dissatisfied university faculty lead to decrease in their efficiency of work.

Job satisfaction is an important factor in faculty appointment and flexible rules or principles are easy to follow and also increase the efficiency in educational institutions. It is clear that job performance of university faculty affected due to job dissatisfaction and it definitely affect their quality of life. Job performance is directly related to job satisfaction and job security. A satisfied university faculty member have feelings of dedication toward work, performs better, and have feelings of care for others and for himself. He feels himself safe in an organization (Dziuba, Ingaldi, \& Zhuravskaya, 2020). Rötze emphasized that there are four factors influencing employee satisfaction. These are as: supervisor/leader, workplace environment, job design and performance pay. The following are the basic factors of job satisfaction.

\section{Job Security}

Each individual have their own set of criteria for determining job satisfaction. The 
main responsible factors are; the administration or leadership style, the duty hours, payments, stress level, working routine and flexibility, and other benefits. Satisfaction of job is directly linked with job performance, productivity, motivation and happiness in life (Abuhashesh et al., 2019). It is clear that personal lives matters are also associated with job satisfaction.

Job security is directly associated with job satisfaction. A satisfied faculty feels safe and better in the university, and definitely show better performance in an organization. That is why job security is an important determinant of job satisfaction (Wolniak \& Olkiewicz, 2019; Niciejewska, 2017). Generally job satisfaction is somewhat linked with the job security (Hong, Hamid, \& Salleh, 2013).

\section{People Management / Faculty Management}

People/faculty management is a vital aspect of an institutional process. A welladministered organization generally appoints the best manpower for the achievements of the organizational objectives. Similarly universities administration recruits and appoints those faculties who are motivated to work, energetic, and have command over their subject etc. For the achievement of the goals and objectives, the institutions provides conducive environment for work and assure its faculty through procedures that facilitate their job satisfaction. Motivated faculty then promote trustworthiness and obligation to the institute which results in greater productivity and lower turnover rate (Parvin, \& Kabir, 2011).

\section{Compensation / Pay}

Compensation can be considered as the financial benefit provided to the workers by the organization as a result of the amenities that the faculty render for the organization. Financial payment and benefits are important considerations for an individual work for maintaining quality life in a society. In the same way, university faculty work with devotion and commitment. But, if they are not paid according to their due efficiency then it leads to job dissatisfaction. When workers experience promotions and increment in payment, then they feel happy and satisfied with their jobs. Compensation package occupies the primary and most important factor in the determination of the job satisfaction (Neog, \& Barua, 2014).

\section{Working Environmental Conditions}

The working environment settings effect job satisfaction, as the staffs could expect their working environmental settings in the workplace should be comfortable and conducive for learning. Working environments related to the office furniture, tools, chairs and machines, etc. The staffs feel satisfied with the job and their efficiency of work increases because of the good working environmental conditions in an organization. In the same way, when the staffs do not find the working environment 
settings in a workplace comfortable and relaxed, they don't develop the feelings of job satisfaction (Kumari, Joshi, \& Pandey, 2014).

\section{Relationship with the Colleagues}

It is very important for the workers/employees to develop appropriate conditions and terms with the colleagues in an organizational setup. It is also important to develop an atmosphere in the working place, where colleagues are able to communicate each other in a pleasurable and comfortable way. Friendly relationships with the colleagues the individual boost to show good performance of their jobs, different assignments and work responsibilities in a satisfactory way. Therefore, amicable terms and relationships with the colleagues permit workers to increase efficiency and output, and improve feelings of job satisfaction. (Parvin, \& Kabir, 2011).

\section{Motivation}

Motivation has been well-defined by academics in a number of ways such as it is a psychological process, it is goal-directed behavior and it also determines an individual's key factor in relation to individual's devotion towards work. The researchers emphasized that, the job satisfaction definitely linked with the chances of improvement. Ellickson and Logsdon (2001) study also supports the belief that the encouraging relationship found between job satisfaction of the individuals and opportunities for advancement. He further identifies that chances for development are the symbol of a motivator factors.

\section{RESEARCH OBJECTIVE}

1. To explore the job satisfaction of the faculty in universities of Azad Jammu and Kashmir

\section{RESEARCH QUESTION}

1. Are the faculties in universities of Azad Jammu and Kashmir satisfied from their job in terms of Job security, Pay and Allowances, Colleague Relationship, University Policies, and working Environment?

\section{METHODOLOGY}

This study was quantitative in nature and survey method was utilized for data collection from the respondents. Quantitative research methods are defined as the collection of data in numerical form and investigation using mathematical approaches in specialized statistics to explain a phenomena or an issue (Aliaga \& Gunderson, 2002).

All the faculty members of social sciences of five public sector universities; University of Poonch Rawalakot, Women University Bagh, Mirpur University of 
Science \& Technology, University of Kotli and University of Azad Jammu \& Kashmir, Muzaffarabad was the population. There were 1080 faculty members serving in different department of social sciences and 541 (50\%) were selected as sample size using the stratified sampling technique.

Survey method was used to collect the relevant data about the study. Self-structured questionnaire was prepared with the help of educational expert in the relevant field to collect the relevant data. Five point Likert scale with options: Strongly agree, agree, neutral, disagree and strongly disagree was used. First part of the questionnaire was based upon the demographic information about the qualification, length of service, designation, gender, marital status and job status. Second part of the questionnaire was related to the job security (3 items), pay and allowances (4 items), colleague relationship ( 2 items), university policies (3 items), working environment (3 items) and physical environment ( 2 items) of the university.

This questionnaire was presented in front of the educational experts to check its validity. Observations were incorporated in the questionnaire and further it was pilot tested upon 65 faculty members excluded from the sample size of the study. Reliability was checked through SPSS Version 17 and the calculated value of alpha was .653 for the indicator of job security, .591 for pay and allowances, .702 for colleague relationship, .641 for university policies, .610 for working environment of the university and .703 for physical environment in the university.

Overall the questionnaire was suitable for the research study. The researcher at first stage collect the data through personal visits in the universities. But due to Covid-19, it was very difficult to collect the relevant data personally. Later on about $40 \%$ data was collected through emails, telephonic calls, google forms and WhatsApp.

\section{RESULTS}

After collecting data the researcher analyzed the questionnaire by finding the frequency, percentage and mean score against the responses of the target sample. Analysis of data done through SPSS.

Table No 1: Job security in University

\begin{tabular}{lcccccc}
\multicolumn{1}{c}{ Statement } & $\begin{array}{c}\text { SDA } \\
\mathbf{\%}\end{array}$ & $\begin{array}{c}\boldsymbol{D A} \\
\boldsymbol{\%}\end{array}$ & $\begin{array}{c}\boldsymbol{N} \\
\mathbf{\%}\end{array}$ & $\begin{array}{c}\boldsymbol{A} \\
\mathbf{\%}\end{array}$ & $\begin{array}{c}\text { SA } \\
\mathbf{\%}\end{array}$ & Mean \\
\hline I am satisfied with & 85 & 117 & 47 & 186 & 106 & 3.21 \\
my job as it is & $15.7 \%$ & $21.6 \%$ & $8.7 \%$ & $34.4 \%$ & $19.6 \%$ & \\
permanent. & & & & & & \\
I am satisfied with & 27 & 99 & 71 & 231 & 113 & 3.56 \\
the university & $5 \%$ & $18.3 \%$ & $13.1 \%$ & $42.7 \%$ & $20.9 \%$ & \\
\hline
\end{tabular}


leave policy for

the faculty.

I feel confident

that I have the

potential to

execute my job

responsibilities in

the university

Table No: 1 indicates respondent's perceptions about the level of satisfaction of their job security. Table shows that of $54 \% \%(\mathrm{SA}=19.6 \%, \mathrm{~A}=34.4 \%)$ university faculty agreed with the statement that they are satisfied with their job as it is permanent. The mean scores of faculty (3.2) also supported their views which falls under the moderate level of satisfaction. Similarly the participants agreed about the leave policy for faculty. Table indicates that majority of faculty $63.6 \%$ ( $\mathrm{SA}=20.9$, $A=42.7)$ agreed with the leave policy for the faculty. The mean scores of faculty (3.5) also supported their views which falls under the high level of satisfaction. Likewise university faculty have potential to execute their job. This table also indicates the majority of the university faculty $54 \%(\mathrm{SA}=19.6 \%, \mathrm{~A}=34.4 \%)$ agreed with the statement that they feel that they have potential to execute their job responsibilities in the university. The mean score of faculty (3.9) also supported their views which fall under the high level of satisfaction.

Table No 2: Pay and Allowances

\begin{tabular}{|c|c|c|c|c|c|c|}
\hline Statement & $\begin{array}{c}\text { SDA } \\
\%\end{array}$ & $\begin{array}{c}D A \\
\%\end{array}$ & $\begin{array}{l}N \\
\%\end{array}$ & $\begin{array}{l}A \\
\%\end{array}$ & $\begin{array}{c}S A \\
\%\end{array}$ & Mean \\
\hline I am happy with & 70 & 108 & 54 & 228 & 81 & 3.2 \\
\hline $\begin{array}{l}\text { the existing } \\
\text { salary structure } \\
\text { of the } \\
\text { university. }\end{array}$ & $12.9 \%$ & $20 \%$ & $10 \%$ & $42.1 \%$ & $15 \%$ & \\
\hline I always receive & 51 & 121 & 48 & 272 & 49 & 3.2 \\
\hline $\begin{array}{l}\text { appropriate } \\
\text { honorarium for } \\
\text { my extra } \\
\text { workload } \\
\text { assigned by the } \\
\text { University }\end{array}$ & $9.4 \%$ & $22.4 \%$ & $8.9 \%$ & $50.3 \%$ & $9.1 \%$ & \\
\hline I am satisfied & 53 & 48 & 110 & 259 & 71 & 3.4 \\
\hline $\begin{array}{l}\text { with the M.Phil. } \\
\text { or Ph.D. }\end{array}$ & $9.8 \%$ & $8.8 \%$ & 20.3 & $47.9 \%$ & $13.1 \%$ & \\
\hline
\end{tabular}




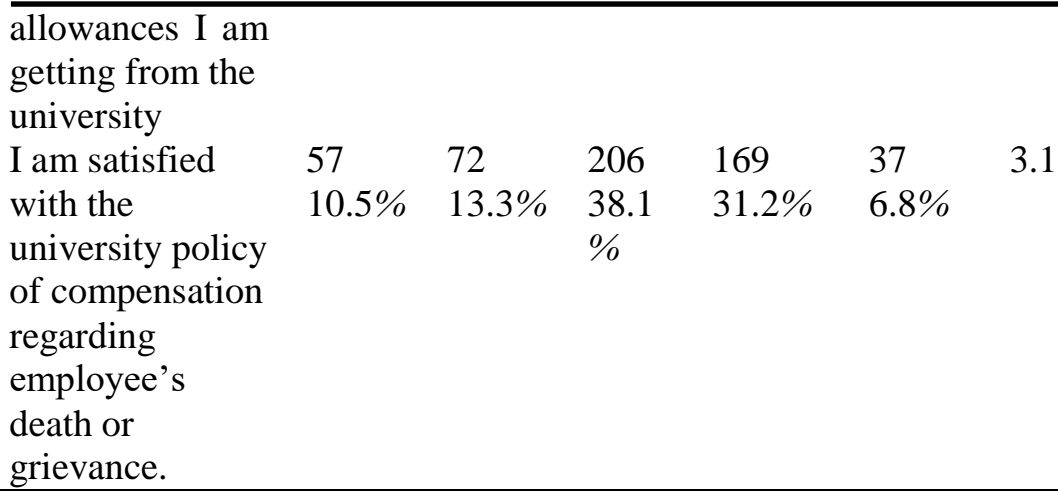

Table No: 2 indicates respondent's perceptions about pay and allowances. Table shows that $57.1 \%(\mathrm{SA}=15 \%, \mathrm{~A}=42.1 \%)$ of university faculty agreed with the statement that they are happy with the existing salary structure of the university. The mean scores of faculty (3.2) also supported their views which falls under the moderate level of satisfaction. Likewise the able shows that $59.4 \%(\mathrm{SA}=9.1 \%$, $\mathrm{A}=50.3 \%$ ) of university faculty agreed that they always receive appropriate honorarium for their extra workload assigned by the University. Mean score (3.27) also falls in the high level of satisfaction. Similarly, table also shows that $61 \%$ ( $\mathrm{SA}=13.1 \%, \mathrm{~A}=47.9 \%)$ of university faculty agreed with the statement that they are satisfied with the M.Phil. or Ph.D. allowances getting from the university. The mean scores of faculty (3.4) also supported their views which falls in the moderate level of satisfaction. Similarly, table also shows that $38.3 \%$ of university faculty was neutral with the statement that they are satisfied with the university policy of compensation regarding employee's death or any grievance. The mean scores of faculty (3.1) also supported their views which falls under the moderate level of satisfaction.

Table No 3: Colleague Relationship

\begin{tabular}{|c|c|c|c|c|c|c|}
\hline Statement & $\begin{array}{c}S D A \\
\%\end{array}$ & $\begin{array}{c}D A \\
\%\end{array}$ & $\begin{array}{l}N \\
\%\end{array}$ & $\begin{array}{l}A \\
\%\end{array}$ & $\begin{array}{c}S A \\
\%\end{array}$ & Mean \\
\hline feel & 52 & 51 & 42 & 224 & 172 & 3.7 \\
\hline $\begin{array}{l}\text { comfortable } \\
\text { with the senior } \\
\text { colleagues as } \\
\text { they guide me } \\
\text { on } \\
\text { academic } \\
\text { problems. }\end{array}$ & $9.6 \%$ & $9.4 \%$ & $7.8 \%$ & $41.4 \%$ & $31.8 \%$ & \\
\hline I always enjoy & 33 & 80 & 34 & 175 & 219 & 3.8 \\
\hline a respectable & $6.1 \%$ & $14.8 \%$ & $6.3 \%$ & $32.3 \%$ & $40.5 \%$ & \\
\hline
\end{tabular}


relationship

with other

faculty

members

Table No: 3 indicates that the respondent's perceptions about colleague relationship. Table shows that majority of university faculty $73.2 \%$ (SA=31.8\%, $\mathrm{A}=41.4 \%)$ agreed with the statement that they feel comfortable with the senior colleagues as they guide them on their academic problems. The mean scores of faculty (3.7) also supported their views which falls under the high level of satisfaction. Similarly the table also shows that majority of university faculty $72.8 \%$ ( $\mathrm{SA}=40.5 \%, \mathrm{~A}=32.3 \%$ ) agreed with the statement that they always enjoy a respectable relationship with other faculty members. The mean scores of faculty (3.8) also supported their responses which fall under the high level of satisfaction.

\begin{tabular}{|c|c|c|c|c|c|c|}
\hline Statement & $\begin{array}{c}S D A \\
\%\end{array}$ & $\begin{array}{c}D A \\
\%\end{array}$ & $\begin{array}{l}N \\
\% \\
\end{array}$ & $\begin{array}{l}A \\
\% \\
\end{array}$ & $\begin{array}{c}S A \\
\%\end{array}$ & Mean \\
\hline $\begin{array}{l}\text { I am satisfied } \\
\text { with the } \\
\text { present } \\
\text { recruitment } \\
\text { policy of the } \\
\text { university }\end{array}$ & $\begin{array}{l}43 \\
7.9 \%\end{array}$ & $\begin{array}{l}105 \\
19.4 \%\end{array}$ & $\begin{array}{l}127 \\
23.5 \%\end{array}$ & $\begin{array}{l}187 \\
34.6 \%\end{array}$ & $\begin{array}{l}79 \\
14.6 \%\end{array}$ & 3.2 \\
\hline $\begin{array}{l}\text { I am satisfied } \\
\text { with the } \\
\text { university Act } \\
\text { and Statutes }\end{array}$ & $\begin{array}{l}99 \\
18.3 \%\end{array}$ & $\begin{array}{l}59 \\
10.9 \%\end{array}$ & $\begin{array}{l}174 \\
32.2 \%\end{array}$ & $\begin{array}{l}170 \\
31.4 \%\end{array}$ & $\begin{array}{l}39 \\
7.2 \%\end{array}$ & 2.9 \\
\hline $\begin{array}{l}\text { I am satisfied } \\
\text { with the } \\
\text { retirement } \\
\text { policy of the } \\
\text { university }\end{array}$ & $\begin{array}{l}65 \\
12 \%\end{array}$ & $\begin{array}{l}48 \\
8.9 \%\end{array}$ & $\begin{array}{l}193 \\
35.7 \%\end{array}$ & $\begin{array}{l}201 \\
37.2 \%\end{array}$ & $\begin{array}{l}34 \\
6.3 \%\end{array}$ & 3.1 \\
\hline
\end{tabular}

Table No: 4 shows respondent's perceptions about the university policies. Table shows that $49.2 \%(\mathrm{SA}=14.6 \%, \mathrm{~A}=34.6 \%)$ of university faculty agreed with the statement that satisfied with the present recruitment policy of the university. The mean scores of faculty (3.2) also supported their views which falls under the moderate level of satisfaction. Likewise the table shows that majority of university faculty $38.6 \%(\mathrm{SA}=31.4 \%, \mathrm{~A}=7.2 \%)$ agreed with the statement that they were satisfied with the university Act and Statutes. The mean scores of faculty (2.9) also 
supported their views that falls in the moderate level of satisfaction. Similarly table shows that $43.5 \%(\mathrm{SA}=6.3 \%, \mathrm{~A}=37.2 \%)$ of university faculty agreed with the statement that satisfied with the retirement policy of the university. The mean scores of faculty (3.1) also supported their views which falls under the moderate level of satisfaction.

Table No 5: Working Environment

\begin{tabular}{|c|c|c|c|c|c|c|}
\hline Statement & $\begin{array}{c}S D A \\
\%\end{array}$ & $\begin{array}{c}D A \\
\%\end{array}$ & $\begin{array}{l}N \\
\%\end{array}$ & $\begin{array}{l}A \\
\%\end{array}$ & $\begin{array}{c}S A \\
\%\end{array}$ & Mean \\
\hline $\begin{array}{l}\text { I am happy with the } \\
\text { existing working } \\
\text { environment in my } \\
\text { institution }\end{array}$ & $\begin{array}{l}85 \\
15.7 \%\end{array}$ & $\begin{array}{l}85 \\
15.7 \%\end{array}$ & $\begin{array}{l}43 \\
7.9 \%\end{array}$ & $\begin{array}{l}273 \\
50.5 \%\end{array}$ & $\begin{array}{l}55 \\
10.2 \%\end{array}$ & 3.2 \\
\hline $\begin{array}{l}\text { I am content with } \\
\text { the working hours of } \\
\text { the university }\end{array}$ & $\begin{array}{l}93 \\
17.2 \%\end{array}$ & $\begin{array}{l}121 \\
22.4 \%\end{array}$ & $\begin{array}{l}79 \\
14.6 \%\end{array}$ & $\begin{array}{l}109 \\
20.1 \%\end{array}$ & $\begin{array}{l}139 \\
25.7 \%\end{array}$ & 3.1 \\
\hline $\begin{array}{l}\text { I am content with } \\
\text { the availability of } \\
\text { resources in my } \\
\text { department } \\
\text { teaching. }\end{array}$ & $\begin{array}{l}94 \\
17.4 \%\end{array}$ & $\begin{array}{l}127 \\
23.5 \%\end{array}$ & $\begin{array}{l}99 \\
18.3 \%\end{array}$ & $\begin{array}{l}126 \\
23.3 \%\end{array}$ & $\begin{array}{l}95 \\
17.6 \%\end{array}$ & 3.0 \\
\hline
\end{tabular}

Table No: 5 shows the respondent's perceptions about the satisfaction with the working environment in the university. Table shows that $60.7 \% \quad(\mathrm{SA}=10.2 \%$, $\mathrm{A}=50.5 \%$ ) of university faculty agreed with the statement that they are happy with the existing working environment in my institution. The mean scores of faculty (3.2) also supported their responses which falls under moderate level of satisfaction. Similarly this table shows that $45.8 \%$ ( $\mathrm{SA}=25.7 \%, \mathrm{~A}=20.1 \%$ ) of university faculty agreed with the statement that they are content with the working hours of the university. The mean scores of faculty (3.1) also supported their views which falls under the moderate level of satisfaction. Likewise the table shows that $40.9 \%$ ( $\mathrm{SA}=17.6 \%, \mathrm{~A}=23.3 \%)$ of university faculty agreed with the statement that they are content with the availability of resources in my department for teaching. The mean scores of faculty (3.0) also supported their responses which falls under the moderate level of satisfaction.

\section{DISCUSSION}

This current study was about the satisfaction level of the university faculty in AJK Muzaffarabad. Muzaffarabad is the capital of the State of Azad Jammu \& Kashmir. Muzaffarabad campus is the oldest and earliest university and it also known as the 
mother university in Azad Jammu \& Kashmir. Results of the study concluded that the faculty members are satisfied because their job is permanent, and they are satisfied with the existing salary structure, M.Phil. Or Ph.D. allowances getting from the university. Continuously increment in income and financial means can lead to increased life and job satisfaction, because money is used to satisfy human needs. Results of the study of Howell et al. (2013) indicated that in older adults as economic standing increases, so a safety need of financial security and minimum risk taking rises, which in turn raises overall job satisfaction among workers. Increasing financial incomes may also support academic staff to satisfy their main academics related requirements. Study of Biswas-Diener and Diener in 2001 also concluded that financial security is a significant result of socio-economic status that effects wellbeing. Increased well-being and salary may be positively interrelated with social support.

Findings of the study showed that the physical facilities of the university are not satisfactory and also they are dissatisfied with the working hours and existing working environment of the university. Same findings of Bakotic \& Babic (2013) revealed that working conditions in an institute is an important element for job satisfaction and workers who work under challenging working conditions are mostly dissatisfied with their job. For the improvement of the satisfaction of staffs working under challenging working conditions, it is compulsory for the management authorities to improve the working conditions in an institute.

The study of Tariq et al (2013) also emphasized that these are the different factors like salary, workload, stressful working conditions at the office and clashes with family due to job leads a worker towards displeasure and dissatisfaction that would results in turnover. According to Chandrasekar (2011), an institute should give special attention to creating a working atmosphere that encourages employees to be more creative in order to get the best possible results. In 2014, Raziq and Maulabakhsh published a study titled "Impact of Working Environment on Job Satisfaction," which found that employees in university, banking, and communications, believe that the work environment plays a significant influence in achieving job satisfaction.

The study of Schneider, (2003) also revealed that proper working environment makes the job relaxed and comfortable. Poor working environments like maintenance and poor building design create conditions for teachers that badly affect not only academic activities and outcome but their health too. Dirty and in-operational windows, poor lighting, and dirty rest rooms are the cause of teacher dissatisfaction in the educational institutes. Plananandanond, Laksana and Jose (2004) researched that overall working environments are able to predict the satisfaction level of the staff 
in the organizations.

\section{CONCLUSION}

On the basis of results, it can be concluded that the university faculty in the five public sector universities of Azad Jammu \& Kashmir are satisfied with their job as it is permanent and they are getting handsome salaries, satisfied with the M.Phil. Or $\mathrm{Ph} . D$. allowances. Senior faculty members help their juniors in academic problems, they have good relationships. However, university faculty is dissatisfied with the physical facilities provided in their department, working hours of university and working environment of the university.

\section{RECOMMENDATIONS}

1. The university faculty is not satisfied with the physical facilities in the AJK universities. Therefore it is recommended that physical facilities should be provided to the departments where necessary.

2. The university faculty is not satisfied with the University Act and Statutes. Therefore it is recommended that Acts and Statutes of AJK Universities may be revised because it is very old and designed in 1981 .

3. The university faculty is not satisfied with the retirement policy of the university because it is very old and designed in 1981. Therefore it is recommended that University Act and statutes of AJK universities may also need to be changed or may be revised on urgent basis.

4. The university faculty is not satisfied with the death compensation and grievance package of employees in the university. It is therefore recommended that the public sector universities in AJK may revise the compensation package and their faculty hence forth this package the case may be approved through the governing bodies.

\section{REFERENCES}

Abuhashesh, M., Al-Dmour, R., Masa'deh, R., 2019. Factors that affect Employees Job Satisfaction and Performance to Increase Customers' Satisfactions, Journal of Human Resources Management Research, 201 (2019),1- 23, DOI: $10.5171 / 2019.354277$.

Aliaga, M. and Gunderson, B. (2002) Interactive Statistics. [Thousand Oaks]: Sage Publications.

Allen, J. A. (2013). Observations of effective teacher-student interactions in secondary school classrooms: predicting student achievement with the classroom assessment scoring system-secondary. School psychology review, 42(1), 76-98.

Armstrong, M. (2006). A Handbook of Human Resource Management Practice. London: Kogan page Publishing.

Azeem, S. M. (2010). Job Satisfaction and Organizational Commitment among Employees in 
the Sultanate of Oman. Scientific Research, 1(4), 295-299.

Bakotic, D. \&. (2013). Relationship between Working Conditions and Job satisfaction: The case of Crotian Shipbuilding Company. International Journal of Business and Social Sciences, 4(2), 206-213.

Bender, K. A., \& Heywood, J. S. (2006). Job satisfaction of highly educated. Scottish Journal of Political Economy, 53(2), 253-279.

Biswas-Diener, R. \&. (2001). making the best of a bad situation: satisfaction in the slums of Calcutta. Social Indicators Research, 53(3), 329-352.

Bollen, K. A. (1989). Structural Equations with Latent Variables (pp. 179-225). John Wiley \& Sons

Brenninger, H-J., 2015. Employee satisfaction and its impact on company value, Doctoral thesis. University Of Latvia, Faculty of Economics and Management, Riga Latvia.

Chand, s. (2020, April 29). Theories of Job Satisfaction and Their Impacts on Worker, employee Management. Retrieved from http://www.yourarticlelibrary.com

Chandrasekar, K. (2011). Workplace Environment and Its impact Organizational performance in Public sector organizations. International Journal of enterprise Computing and Business Systems, 1-19.

Dziuba.T.S. Ingaldi.M., \& Zhuravskaya.M. (2020). Employees' Job Satisfaction and their Work Performance as Elements Influencing Work Safety. System Safety: Human Technical Facility - Environment, 2(1), 18-25.

Ellickson, M. C., \& Logsdon, K. (2001). Determinants of job satisfaction of municipal government administrative staff. State \& Local Government Review, 7(1), 173-184. https://doi.org/10.1177/0160323X0103300302

Fairman, J. \&. (2012). Spheres of Teacher Leadership Action for Learning. Professional development in education, 38(2), 229-246.

Hagedorn, L. S. (1994). Retirement proximity's role in the prediction of satisfaction in academe. Research in Higher Education, 35(6), 711-728.

Hong, L. H. (2013). A study of the Factors Affecting Job Satisfaction amongst employees of a Factory in Seremban, Malaysia. Business Management Dynamics, 3(1), 26-40.

Howell, R. K. (2013). Money Buys Financial Security and Psychological Need Satisfaction: Testing Need Theory in affluence. Social Indicators Research, 110(1), 17-29.

Huseman, R, Hatfield, J, \& Miles E. (1987) 'A new perspective on Equity Theory'. TheEquity Sensitivity Construct', Academy of Management Review. 12 (2), 232- 234

Jawarbi. A., (2017).Job satisafaction of academic staff of higher education: Evident from private universities in UAE. International Journal of Human Resource Studies, 7 (4), 193-211

Jones, C. (2009). Moral Leadership: An Investigation of Global Dimension Leadership in Uk School. Uk: MA Ddiss. Middlesex University.

Kaliski, B. (2007). Encyclopedia of Business and Finance. Detroit: Thomson Gale.

Kumari, G. J. (2014). Analysis of Factors Affecting Job Satisfaction of the Employees in Public and Private Sector. IJTEMT, 3(1), 11-19.

Lo, M. C., \& Ramayah, T. (2011). Mentoring and job satisfaction in Malaysian SMEs. Journal of Management Development, 30(11), 427-440.

Mullins, J. (2005). Management and Organizational Behaviour. Pearson Education Limited. Neog, B. \&. (2014). Factors Influencing employee's Job Satisfaction: An Empirical Study 
among Employees of automobile Service Workshops in Assam. The SIJ Transaction on Industrial, Financial \& Business Management, 10(5), 305-316.

Ololube, N. (2005). Benchmarking the Motivational competencies of Academically Qualified teachers and Professionally Qualified Teachers in Nigerian Secondary Schools. The African Symposium, 5(1), 17-37.

Parvin, M. \&. (2011). Factors Affecting Employee Job Satisfaction of the Pharmaceutical sector. Australian Journal of Business and Management research, 1(9), 113-123.

Pilanandanond, M, Jose, J. K. and Lakasna, S. (2004) 'The relationship among working conditions, job satisfaction and teachers' performance in private schools under Kottayam cooperative agency, Kerala, India. Journal of Management and Sustainability, 24(6), 141-154

Raziq, A. (2014). Impact of working Environment on Job Satisfaction. Procedia Economic and Finance, 4(1), 717-725.

Scatt, D. (2004). The Routledge Dictionary of Business Management. Detroit: Routledge Publishing.

Schneider, M. (2002) 'Do school facilities affect academic outcomes? Washington, D.C.: National Clearinghouse for Educational Facilities. (Cited 8 March, 2006) available from www.edfacilities.org/pubs/teachersurvey.

Sonmezer, M. G., \& Eryaman, M. Y. (2008). A comparative analysis of job satisfaction level of public and private schools. Journal of Theory and Practice in Education, 4(2), $189-212$

Spector, P. (1997). Job Satisfaction: Application, assessment, causes and consequences. Thousand Oaks: CA, Sage Publishers, Inc.

Sukamolson, S. (2007). Fundamentals of quantitative research. Language Institute Chulalongkorn University, 6(10), 1-20.

Szromek. A. R., \& Wolniak.R. (2020). Job Satisfaction and Problems among Academic Staff in Higher Education.sustainability.12 (12), 48-65; https://doi.org/10.3390/su12124865

Tai.F.M. \& Chaung.P.Y., (2014).Job satisfaction of University Staff. The Journal of Human Resource and Adult Learning. 10 (1), 51-64

Usmani, S. A. A., \& Tabassum, H. (2018). Islamic Education with the help of Information Technology: Advantages and Disadvantages. The Islamic Culture" As-Saqafat-ul Islamia" الثقافة الإسلامية-Research Journal-Sheikh Zayed Islamic Centre, University of Karachi, (40).

Tariq, m. R. (2013). The impact of Employee Turnover on the efficiency of the organization. Interdisciplinary Journal of Contemporary research in Business, 4(9), 700-711.

Waster, E.E, Berscheid, G.A \& Waster, G. W (1973). 'New Dimensions in Equity Research' Journal of Personality and Social Psychology .25(2), 151-176

Wolniak, R., Olkiewicz, M., 2019. The Relations between Safety Culture and Quality Culture, System Safety: Human - Technical Facility - Environment, International Journal of Library Sciences. 9 (2), 40-50. DOI: 10.2478/czoto-2019-0002. 